\title{
A RURAL-BASED MEDICAL AND SOCIOLOGICAL STUDY ON THE RESULTS OF THE PRIMARY CARE REFORM
}

DOI: 10.36740/WLek202005123

\author{
Volodymyr I. Potseluiev', Andriana M. Kostenko' , Lesia A. Rudenko², Olha I. Smiianova' \\ 'SUMY STATE UNIVERSITY, SUMY, UKRAINE \\ ${ }^{2}$ ALUNA PUBLISHING HOUSE, KONSTANCIN-JEZIORNA, POLAND
}

\begin{abstract}
The aim: To study the results of a medical and sociological research as to the attitude of rural population in amalgamated hromadas (AH), i.e. united territorial communities, of Sumy region to the results of primary care reform.

Materials and methods: The form of research - a survey with closed questionnaire. The study was conducted on a specially designed three-tier quota sample, which was calculated allowing for the territorial and socio-demographic indicators. A total of 320 respondents residing in the specified rural communities (hromadas) were surveyed with quota sampling. The theoretical sampling error makes $3 \%$. The questionnaires were processed by the laboratory staff with the help of the "OCA" program.

Results: Among the surveyed in Nyzhniosyrovatska AH (amalgamated hromada), 23.5\% of the population emphasized that their authorities neglected medical problems, while in Bezdrytska AH this indicator was 6.7\%, as evidenced by the difference in the industry financing from own assets (274 thousand less than in Bezdrytska AH).

The survey revealed that in the communities where the population knows their family doctors better and trusts them, the satisfaction with the quality of medical care and the attitude to prophylaxis (prevention) is much higher.

Conclusions: A significant part of the population demonstrates a low level of awareness of the course of the reforms, their goals and objectives. The specified trends may indicate a lack of communication or distortion of information on the implementation of medical reform. It is an information support that is one of the key instruments for effective introduction of medical reform. At the local level, this function is assigned to a family doctor who becomes a determining factor not only for providing medical services to patients, but also for communication, keeping the population informed and prophylaxis.
\end{abstract}

KEY WORDS: medical reform, quality of care, prevention, affordability

Wiad Lek. 2020;73(5):963-966

\section{INTRODUCTION}

Primary care is the basic assistance in the prevention, diagnosis and treatment provided on the basis of equality and affordability [1]. Within the framework of health care reform, considerable attention is paid to rural medicine. It is not just about the redecoration of rural health facilities, but about the new quality of health services in rural areas.

Public Health Department of Medical Institute attached to Sumy State University [2] and Central District Hospital in cooperation with the problematical laboratory "Center for Social and Humanitarian Aspects of Regional Studies" of Sumy State University [3] during September-October 2019 conducted a sociological survey of the residents of Bezdrytska and Nyzhniosyrovatska rural amalgamated hromadas of Sumy region to assess the state of satisfaction with the health care system.

Selection of Bezdrytska and Nyzhniosyrovatska rural amalgamated hromadas of Sumy district, Sumy region is conditioned by relatively identical socio-demographic indicators, materials and staffing of healthcare industry, as well as geographical location to the regional center - Sumy. In addition, according to the assessment of their capacity, both rural communities are classified by the Ministry of Regional Development as capable, which indicates their ability to provide the population with all the necessary social services, including medical ones.

\section{THE AIM}

To study the results of medical and sociological research on the attitude of rural population in the amalgamated hromadas (AH) of Sumy region to the results of primary care reform.

\section{MATERIALS AND METHODS}

The study was carried out in two stages. At the first stage, a programme and tools were developed, sampling was organized, and routes were worked out. At the second stage, fieldwork was conducted (collecting information, checking the work of interviewers, discarding questionnaires), computer processing was performed, the tables were compiled and the report was prepared. The questionnaires were processed by the laboratory staff using the "OCA" programme.

The form of the research - a survey with the help of a closed questionnaire. The study was conducted in accordance with a specially designed three-tier quota sample, which was calculated with allowance for the territorial 
Table I. What priorities would you define for your community

\begin{tabular}{ccccccccc}
\hline & $\begin{array}{c}\text { Infrastructure } \\
\text { development }\end{array}$ & $\begin{array}{c}\text { Development } \\
\text { of education } \\
\text { culture }\end{array}$ & $\begin{array}{c}\text { Development } \\
\text { of healthcare } \\
\text { sphere }\end{array}$ & Development & $\begin{array}{c}\text { Investment } \\
\text { attraction }\end{array}$ & $\begin{array}{c}\text { Job } \\
\text { creation }\end{array}$ & $\begin{array}{c}\text { Social } \\
\text { support }\end{array}$ & $\begin{array}{c}\text { Difficult } \\
\text { to } \\
\text { answer }\end{array}$ \\
\hline Bezdrytska AH & 39.5 & 33.6 & 39.5 & 12.6 & 19.3 & 31.1 & 19.3 & 9.2 \\
\hline Nyzhniosyrovatska AH & 29.7 & 18.9 & 37.8 & 16.2 & 21.6 & 40.5 & 16.2 & 0 \\
\hline
\end{tabular}

Table II. How are you satisfied or not satisfied with the medical care currently provided in your AH?

\begin{tabular}{ccccc} 
& Satisfied & Rather satisfied & Rather not satisfied & Not satisfied \\
\hline Bezdrytska AH & 42.9 & 32.8 & 21 & 3.4 \\
\hline Nyzhniosyrovatska AH & 35.1 & 24.3 & 24.3 & 16.2 \\
\hline
\end{tabular}

Table III. What are the major health care problems in your AH?

\begin{tabular}{|c|c|c|}
\hline & Bezdrytska AH & Nyzhniosyrovatska AH \\
\hline Informal payments to doctors & 6.7 & 8.1 \\
\hline Lack of professionalism in medical staff & 10.1 & 40.5 \\
\hline Accessibility to particular specialists & 29.4 & 35.1 \\
\hline Lack of modern equipment & 36.1 & 40.5 \\
\hline Disregard for medical problems by $\mathrm{AH}$ management & 6.7 & 23.5 \\
\hline Underfunding of the medical system from the local budget & 10.1 & 13.5 \\
\hline No outpatient clinic & 0.8 & 2.7 \\
\hline No hospital & 5.9 & 16.2 \\
\hline No pharmacy & 61.3 & 8.1 \\
\hline High cost of treatment & 17.6 & 8.1 \\
\hline Lack of prevention system & 5.9 & 15.4 \\
\hline Neglect of environmental problems & 10.1 & 0 \\
\hline No problems & 9.2 & 8.1 \\
\hline
\end{tabular}

Table IV. Are changes in the health care system necessary on the whole?

\begin{tabular}{ccc} 
& Yes, necessary & No, not necessary \\
\hline Bezdrytska AH & 84.9 & 15.1 \\
\hline Nyzhniosyrovatska AH & 97.3 & 2.7 \\
\hline
\end{tabular}

and socio-demographic indicators. A total of 320 respondents residing in the specified rural communities were surveyed on a quota sample. The theoretical sampling error makes $3 \%$.

\section{RESULTS AND DISCUSSION}

The population of Bezdrytska amalgamated hromada $(3,591$ people) receives primary medical care in two municipal non-profit enterprises: "Family medicine general practice outpatient clinic" (hereinafter-FMGPOC). In its turn, the population of Nyzhniosyrovatska amalgamated hromada (6,035 people) refers to the municipal non-profit enterprise "Central family medicine general practice outpatient clinic of the village of Nyzhnia Syrovatka" which includes two FMGPOCs.

In 2018, actual expenditures for "Family medicine general practice outpatient clinic of the villages of Bezdryk and Tokari" amounted to 2,304.8 thousand UAH including
751.1 thousand UAH through medical subvention [4]. Similarly, the expenditures for the maintenance of MNE (municipal nonprofit enterprise) of "Central family medicine general practice outpatient clinic of the village of Nyzhnia Syrovatka" in 2018 amounted to 2,904 thousand UAH, of which 1,625 thousand UAH due to medical subvention [5]. The amount of financing for the medical sector from own funds is 274 thousand UAH higher in Bezdrytska AH than in Syrovatska one.

Thus, as we can see, the levels of financing the medical sector in Bezdrytska and Nyzhniosyrovatska rural AHs are comparable. Nevertheless, the amount of medical subvention in Nyzhniosyrovatska AH twice exceeds, although the survey results indicate that with the same amount of financing people differently evaluate the state of medical sector and the quality of health services in their communities.

To the question "What priorities would you define for your community?" respondents specified: development of infrastructure (roads), development of the medical sphere and job creation. From Table I it can be seen that the residents of both AHs refer the medical sphere to the priorities for their community.

The highest priorities of Bezdrytska $\mathrm{AH}$ include the development of infrastructure (39.5\%), whereas Nyzhniosyrovatska AH - creating jobs (40.5\%). 
Table V. What would you like to see as a result of changes in the health system?

\begin{tabular}{cccccccccc}
\hline & Correct & $\begin{array}{c}\text { Opportunities } \\
\text { diagnosis }\end{array}$ & $\begin{array}{c}\text { Reduced } \\
\text { prevention } \\
\text { medical } \\
\text { expenses }\end{array}$ & $\begin{array}{c}\text { Introduction } \\
\text { of specialist } \\
\text { doctors in } \\
\text { medical } \\
\text { institutions }\end{array}$ & $\begin{array}{c}\text { Getting } \\
\text { help close } \\
\text { to home }\end{array}$ & $\begin{array}{c}\text { Availability } \\
\text { of polyclinic } \\
\text { and } \\
\text { hospital in } \\
\text { AH }\end{array}$ & $\begin{array}{c}\text { No } \\
\text { Other }\end{array}$ & $\begin{array}{c}\text { Hard } \\
\text { to say } \\
\text { changes } \\
\text { are } \\
\text { required }\end{array}$ \\
\hline Bezdrytska AH & 39.5 & 11.8 & 30.3 & 20.2 & 20.2 & 11.8 & 1.7 & 16.8 & 5 \\
\hline Nyzhniosyrovatska AH & 75.7 & 16.2 & 32.4 & 16.2 & 16.2 & 10.8 & 2.7 & 0 \\
\hline
\end{tabular}

Table VI. Do you know your family doctor?

\begin{tabular}{ccc}
\hline & Yes & No \\
\hline Bezdrytska AH & 63.9 & 36.1 \\
\hline Nyzhniosyrovatska AH & 48.6 & 51.4 \\
\hline
\end{tabular}

Table VII. Have you signed a declaration with your family doctor?

\begin{tabular}{cccc} 
& Yes & $\begin{array}{c}\text { No, } \\
\text { but I tried }\end{array}$ & $\begin{array}{c}\text { No, I didn't } \\
\text { even try }\end{array}$ \\
\hline Bezdrytska AH & 73.1 & 9.2 & 17.6 \\
\hline Nyzhniosyrovatska AH & 78.4 & 10.8 & 10.8 \\
\hline
\end{tabular}

Table VIla. Have you ever addressed to medical professionals for a preventive purpose?

\begin{tabular}{cccc}
\hline & Yes & No & Difficult to say \\
\hline Bezdrytska AH & 48.7 & 42 & 9.2 \\
\hline Nyzhniosyrovatska AH & 20.5 & 63.2 & 16.2 \\
\hline
\end{tabular}

Along with this, the study conducted allows us to conclude that there are mixed assessments by the population of the existing levels of medical care. So, to the question "How are you satisfied or not satisfied with the medical care that is currently provided in your AH?" respondents give significantly different answers. $42.9 \%$ of respondents from Bezdrytska AH noted that they were satisfied with the medical care in their $\mathrm{AH}$, and another $32.8 \%$ were rather satisfied. That is, the total percentage of satisfaction with medical services in Bezdrytska AH makes about 75\% (Table II).

In turn, in N. Syrovatka only $35.1 \%$ of the population are satisfied with the medical care in their $\mathrm{AH}$, and another $24.3 \%$ are rather satisfied. That is, the total percentage of satisfaction with medical services in Nyzhniosyrovatska $\mathrm{AH}$ is only about $59 \%$.

At the same time, the answers to the question "What are the major healthcare problems in your $\mathrm{AH}$ ?" reveal the inconsistency in people's general assessment of medical care condition in rural AHs on certain characteristics and indicate the presence of serious problems. From Table III we can see that underfunding of the medical system and AH authorities' disregard for medical problems correlate with negative assessments of community health services. Thus, in Nyzhniosyrovatska AH, the highest positions were given to problems related to lack of professionalism in medical personnel, lack of modern equipment (40.5\% of respondents each) and accessibility to specialist doctors (35.1\%). That is, not only the state of material and technical base is an acute problem in the community, but also the issues of staffing.

In its turn, the population of Bezdrytska $\mathrm{AH}$ is more concerned with the lack of a drugstore (61.3\%) and the lack of modern equipment (36.1\%). At the same time, $23.5 \%$ of the population in Nyzhniosyrovatska community noted that the $\mathrm{AH}$ authorities neglected the problems of medicine, whereas in Bezdrytska AH only 6.7\% think so.

Unfortunately, the problems of disease prevention and ecology are not a priority among the population of both communities. The majority of the population believe that financing of medicine should come not from local, but from the state budget.

The fact that the health care system is far from satisfactory and needs to be improved is also evidenced by the answers to the questions about the need for such changes. Thus, $97.3 \%$ of respondents from N. Syrovatka consider that the health care system requires changes. In Bezdryts$\mathrm{ka} \mathrm{AH}$, the above-mentioned position is slightly lower, however still high and makes $84.9 \%$ (Table IV).

Analysis of the answers to the question "What would you like to see as a result of changes in the health care system?" allows you to detail the desired changes resulting from medical reform and leads to the conclusion that respondents see potential changes in different ways. Respondents had the opportunity to choose several answer options, so the total amount of their answers exceeds $100 \%$.

Thus, the most desirable in Nyzhniosyrovatska AH is the correct diagnosis (75.7\%), and in Bezdrytska - access to specialized medical professionals (20.2\%) (Table V). That is, in Nyzhniosyrovatska rural community the matter of insufficient technical equipment and professionalism of medical workers is particularly acute, while in Bezdrytska $\mathrm{AH}$ - the need to improve organizational decisions regarding accessibility to specialist doctors.

That is, the issues of diagnosing and increased accessibility, as well as referral of patients to specialized medical professionals (specialist doctors) are the key issues which are within the competence of the family physician and $\mathrm{AH}$ authorities. Therefore, the improvement of primary care and the arrangement of family doctor's work are crucial in rural communities.

As the survey results show, about $64 \%$ of Bezdrytska $\mathrm{AH}$ respondents know their family doctor, but in Nyzhniosyrovatska community this figure reaches only $48 \%$ (Table VI).

At the same time, approximately identical number of patients have a declaration signed by a family doctor (Table VII). 
Table VIII. What are the main reasons for not contacting health workers for preventive purposes.

\begin{tabular}{cccccccc}
\hline & $\begin{array}{c}\text { There was } \\
\text { no need }\end{array}$ & $\begin{array}{c}\text { I do not consider } \\
\text { it necessary }\end{array}$ & $\begin{array}{c}\text { Couldn't get to medical } \\
\text { facility }\end{array}$ & $\begin{array}{c}\text { There was no } \\
\text { money }\end{array}$ & $\begin{array}{c}\text { Consulted a } \\
\text { Othertor }\end{array}$ \\
\hline Bezdrytska AH & 23.6 & 15.2 & 0.8 & 6.7 & 5 & 48.7 \\
\hline Nyzhniosyrovatska AH & 25.1 & 40.9 & 5.4 & 5.4 & 2.7 & 20.5 \\
\hline
\end{tabular}

Therefore, we can report on a certain indifference of people to their own health, as well as the formality of the procedure for signing the declaration, because patients sign the declaration without knowing their doctor.

When asked "Have you ever consulted a family doctor for a preventive purpose?" only $48.7 \%$ in Bezdrytska $\mathrm{AH}$ and $20.5 \%$ in Nyzhniosyrovatska AH addressed to a family doctor. It is indicative enough that some of the respondents did not go to a family doctor throughout the year (about 42-43\% in Bezdrytska AH, 63.2\% in Nyzhniosyrovatska $\mathrm{AH})$. That is, the frequency of visits to a family doctor indicates the mixed results of the reform at the level of $\mathrm{AH}$, since annual preventive visits to a family doctor are essential components of early diagnoses.

The main reasons for respondents not to address to medical workers for preventive purposes are lack of need (23.6\% in Bezdrytska AH and 25.1\% in Nyzhniosyrovatska $\mathrm{AH})$ and that they do not consider it necessary $(26.2 \%$ in Nyzhniosyrovatska AH and $11.8 \%$ - in Bezdrytska, respectively) (Table VIII).

\section{CONCLUSIONS}

1. The AH population considers the medical sphere as a priority area for community development. The $\mathrm{AH}$ authorities should be aware of the importance of the medical sphere and pay sufficient attention not only to building community infrastructure, but also to the issues of affordability and quality of medical services.

2. Among the respondents in Nyzhniosyrovatska $\mathrm{AH}$, $23.5 \%$ of the population noted that their authorities neglected medical problems, while in Bezdrytska $\mathrm{AH}$ this indicator was $6.7 \%$, which is confirmed by the difference in financing the industry from own funds (274 thousand less than in Bezdrytska $\mathrm{AH}$ ).

3. The survey showed that in thosed communities where the population knows their family doctors better, trusts them, satisfaction with the quality of medical care and attitude to prevention is much higher.

4. A significant part of the population demonstrates a low level of reform awareness, reform goals and objectives. The specified trends may testify to the insufficient level of communication or distortion of information regarding the implementation of health reform provisions. It is information support that is one of the key tools for the effective implementation of medical reform. At the local level, this function is assigned to a family doctor, on whom not only the delivery of medical services to patients depends, but also arranging communication, public awareness and prevention.

\section{REFERENCES}

1. Rus'kykh K. Reformuyte pervynnu medychnu dopomohu v Tsentral'niy ta Skhidniy Yevropi. Uroky dlya Ukrayiny [Reform primary health care in Central and Eastern Europe. Example for Ukraine]. Available from: https://eba.com.ua/static/members_reviews/Case_Study_1_2013_ ukr.pdf

2. Official site of Public Health Department of Sumy State University. Available from: https://social.med.sumdu.edu.ua/index.php/uk/

3. Official site of Center for Social and Humanitarian Aspects of Regional Studies of Sumy State University. Available from: http://csgard.sumdu. edu.ua/uk/

4. Official site of Bezdrytska rural amalgamated hromada. Available from: http://bezdrycka.gromada.org.ua/news/1561119985/

5. Official site of Nyzhniosyrovatska rural amalgamated hromada. Available from: https://nyzhnosyrovatska.rada.today/wp-content/ uploads/2019/02/zvit-silskogo-golovy-za-2018-rik.pdf

\section{ORCID and contributionhip:}

Volodymyr I. Potseluiev - 0000-0003-2140-4058 A,B,C,D

Andriana M. Kostenko - 0000-0002-8970-4244 B,C,D,E

Olha I. Smiianova - 0000-0001-5823-924X ${ }^{E, F}$

Lesia A. Rudenko - 0000-0003-0556-8263 C,E,F

\section{Conflict of interest:}

The Authors declare no conflict of interest

\section{CORRESPONDING AUTHOR Andriana M. Kostenko}

2, Rymskogo-Korsakova st., 40007 Sumy,Ukraine

tel: +380509741149

e-mail: kostenkopr@ukr.net

Received: 27.01 .2020

Accepted: 30.03 .2020

A - Work concept and design, B - Data collection and analysis, C - Responsibility for statistical analysis,

D-Writing the article, $\mathbf{E}$-Critical review, $\mathbf{F}$ - Final approval of the article 